\title{
p53 expression in patients with ulcerative colitis - associated with dysplasia and carcinoma: a systematic meta-analysis
}

\author{
Xiaohong Lu*, Yuanjie Yu and Shiyun Tan
}

\begin{abstract}
Background: Tumor suppressor gene p53 expression has been reported in patients with ulcerative colitis (UC). However, the correlation between p53 expression and UC remains controversial. The aim of this meta-analysis was to investigate the association between p53 expression and different pathological types of UC.

Methods: Publications were searched in the PubMed, Embase, EBSCO, Wangfang, and CNKI databases. The overall odds ratios (ORs) and their corresponding 95\% confidence intervals ( $95 \% \mathrm{Cls}$ ) were summarized in this study.

Results: Final 19 papers were identified in this meta-analysis, including 1068 patients with UC and 130 normal tissue samples. Immunohistochemical p53 expression was significantly higher in UC without dysplasia and carcinoma (UC group) compared to normal tissue samples $(\mathrm{OR}=3.14, P=0.001)$, higher in UC with dysplasia than in UC group $(\mathrm{OR}=10.76, P<0.001)$, and higher in UC with colorectal cancer $(C R C)$ than in $U C$ with dysplasia $(O R=1.69, P=0.035)$. Subgroup analysis of ethnicity (UC group vs. normal tissues) showed that p53 expression was correlated with UC in Asians, but not in Caucasians. When UC with dysplasia was compared to UC group, p53 expression was linked to UC with dysplasia among both Asians and Caucasians. When UC-CRC was compared to UC with dysplasia, p53 expression was not associated with UC-CRC in both Caucasians and Asians.
\end{abstract}

Conclusions: p53 expression was closely associated with UC-CRC development. p53 expression showed different ethnic characteristics among different pathological types of UC.

Keywords: p53, Ulcerative colitis, Dysplasia, Carcinoma

\section{Background}

As one common pathological type of inflammatory bowel diseases (IBD), ulcerative colitis (UC) is characterized by a relapsing, idiopathic, and chronic inflammatory disease which usually affects the entire colon and rectum $[1,2]$. The prevalence of this disease has been rising in the world, patients with UC are correlated with an increased risk of developing colorectal cancer (CRC) [3, 4].

Although the exact mechanism of UC is not fully understood, increasing evidence reports that genetic and environmental factors are important in the pathogenesis of UC [5-7]. Given the increased risk of CRC in UC, dysplasia is precancerous lesions, it is essential to clinical screening of UC patients with dysplasia [8]. The $p 53$, a

\footnotetext{
* Correspondence: luxiaohong@medmail.com.cn Departmemt of gastroenterology, Renmin Hospital of Wuhan University, Jiefang Road 238, Wuhan 430060, China
}

key tumor-suppressor gene (TSG), is mapped to the short arm of chromosome 17 (17p13) [9]. p53 gene encodes the $\mathrm{p} 53$ protein and is responsible for the regulation of cell cycle, DNA repair, and apoptosis $[10,11]$. The $p 53$ mutation is the most common event in human carcinomas, due to the accumulation of mutant $p 53, \mathrm{p} 53$ protein often shows nuclear staining, which makes it easily detected using immunohistochemistry (IHC) method [12, 13]. The expression of $\mathrm{p} 53$ protein can be measured by IHC in different histological types of UC [14, 15].

Although $\mathrm{Du}$ et al. reported the association between KRAS and TP53 mutations with IBD-associated colorectal cancer [16], the correlation between p53 expression and the risk of dysplasia and cancer in patients with UC remained to be elucidated. Because the sample size of an individual study was small in UC, moreover, there were some inconsistent results with respect to p53 expression 
in UC. For example, Li 2004 et al. reported that no immunoreactivity for p53 expression was found in UC and normal tissue samples [17]. Klump 1997 et al. reported that p53 expression was noted in UC without dysplasia/carcinoma and UC with dysplasia [15]. Thus, we first conducted this meta-analysis involving more eligible articles to determine the correlation between p53 expression and different histological types of UC, including normal tissue samples, UC without dysplasia/ carcinoma, UC with dysplasia, and UC with CRC.

\section{Methods}

\section{Search strategy}

A systematic literature search was conducted in the PubMed, Embase, EBSCO, Wangfang, and CNKI databases prior to February 13th, 2017. We used the relevant key words and search terms to identify eligible papers: (inflammatory bowel disease OR ulcerative colitis) AND expression AND (TP53 OR p53 OR p53 protein). The references of the included papers were also carefully checked to get other potential studies.

\section{Study selection}

The eligible publications should meet the following inclusion criteria: 1) patients were diagnosed with UC by pathological examination; 2) normal tissue samples belonged to normal control group, UC groups included UC without dysplasia/carcinoma, UC with dysplasia, and UC with colorectal cancer; 3) studies on the immunohistochemical determination of $\mathrm{p} 53$ protein expression provided sufficient information to determine the relationship between p53 expression and UC. Only the most complete article with more information was selected in this meta-analysis when authors published multiple articles using the same study population.

\section{Data extraction and quality assessment}

According to the above inclusion criteria, two independent authors reviewed and extracted information from the eligible articles: first author's surname, year of publication, country, number of patients, cut-off values, rate of p53 expression, staining location, and the total number of patients in UC and normal control groups. Any controversial issue was discussed by all authors. The quality of the eligible publications was assessed based on the Newcastle-Ottawa Scale (NOS), ranging from 0 to 9. Studies with 6 or more scores were considered to be of high quality [18].

\section{Statistical analysis}

Stata software, version 12.0 (STATA Corp., College Station, TX, USA) was used in this meta-analysis. The overall odds ratios (ORs) and their corresponding 95\% confidence intervals (95\% CIs) were calculated to estimate the strength of the relationship between p53 expression and UC risk. Possible heterogeneity among reported studies was measured using the Cochran's Q statistic [19]. The random-effects model was chosen in the present study. A $P$ value of $<0.1$ for the Q-test showed a substantial heterogeneity, a sensitivity analysis was conducted to evaluate the influence of one study on the pooled results by omitting a single study [20]. For the pooled data with more than eight studies, Egger's test was performed to determine possible publication bias [21].

\section{Results}

Characteristics of the eligible studies

As indicated in Fig. 1, 555 potential papers were initially searched from a range of online electronic databases (PubMed, Embase, EBSCO, Wangfang, and CNKI). According to the above study selection, final 19 articles published from 1993 to 2013 [14, 15, 17, 22-37] were identified in the current meta-analysis, including 1068 patients with UC and 130 normal tissue samples. Nine studies evaluated the correlation of p53 expression in UC versus normal tissue samples. 11 studies evaluated the correlation of p53 expression in UC with dysplasia versus UC without dysplasia and carcinoma. 16 studies evaluated the relationship of p53 expression in UC with carcinoma versus UC with dysplasia. All studies met a score of equal to or greater than 6 in this meta-analysis (Additional file 1: Table S1). Table 1 lists the baseline characteristics of the included studies.

\section{Association of $\mathrm{p} 53$ expression in UC without dysplasia and carcinoma versus normal tissue samples}

The result of 233 patients with UC vs 130 normal tissue samples demonstrated that the level of p53 expression was notably increased in UC compared with normal tissue samples $(\mathrm{OR}=3.14,95 \% \mathrm{CI}=1.58-6.24$, $P=0.001)$ (Fig. 2).

Subgroup analysis by ethnicity (Asians and Caucasians) showed that $\mathrm{p} 53$ expression was linked to Asians with UC $(\mathrm{OR}=2.85,95 \% \mathrm{CI}=1.25-6.47, P=0.012)$, but was not correlated with Caucasians with UC $(\mathrm{OR}=3.49,95 \%$ $\mathrm{CI}=0.85-14.34, P=0.083)($ Table 2$)$.

\section{Association of $\mathrm{p} 53$ expression in UC with dysplasia versus UC without dysplasia/carcinoma}

The result showed that the frequency of p53 expression was notably higher in UC with dysplasia than in UC without dysplasia/carcinoma $(\mathrm{OR}=10.76,95 \% \mathrm{CI}=4.63-25.03$, $P<0.001$ ), including 297 UC patients with dysplasia and $335 \mathrm{UC}$ patients without dysplasia and carcinoma (Fig. 3).

According to ethnic population (Asians and Caucasians) (Table 2), subgroup analysis showed that p53 expression was correlated with UC with dysplasia in the Asian and 


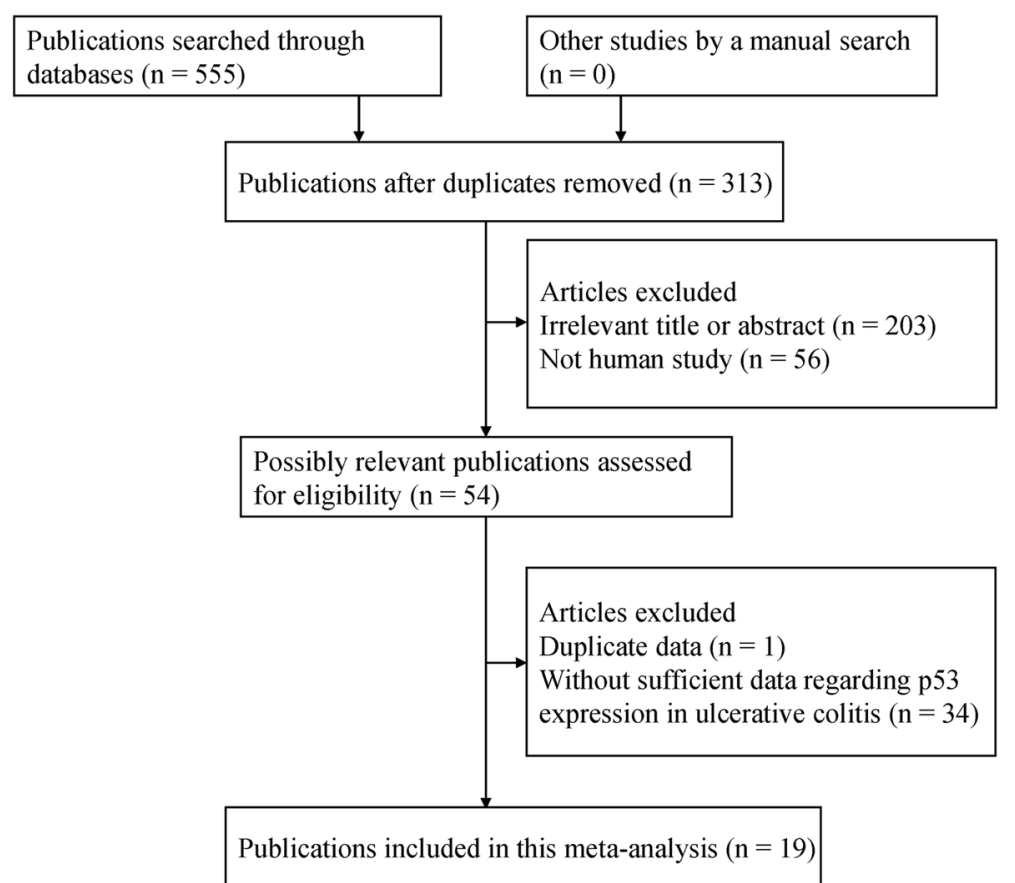

Fig. 1 Flowchart summarizing literature search strategy and selection of studies

Table 1 General characteristics of the eligible publications in this study

\begin{tabular}{|c|c|c|c|c|c|c|c|c|c|c|}
\hline \multirow[t]{2}{*}{ First author } & \multirow[t]{2}{*}{ Country } & \multirow[t]{2}{*}{ Ethnicity } & \multirow[t]{2}{*}{ Age } & \multirow[t]{2}{*}{ Cut-off (IHC) } & \multirow[t]{2}{*}{ Location } & \multirow{2}{*}{$\begin{array}{l}\text { Normal } \\
\text { N (E\%) }\end{array}$} & \multirow{2}{*}{$\begin{array}{l}\text { UC } \\
N(E \%)\end{array}$} & \multirow{2}{*}{$\begin{array}{l}\text { UC with dysplasia } \\
\text { N (E\%) }\end{array}$} & \multirow{2}{*}{$\begin{array}{l}\text { UC with cancer } \\
\text { N (E\%) }\end{array}$} & \multirow[t]{2}{*}{ NOS } \\
\hline & & & & & & & & & & \\
\hline Taylor 1993 [29] & UK & Caucasians & NA & NA & Nucleus & & $20(0)$ & $20(30)$ & $21(52.4)$ & 9 \\
\hline Harpaz 1994 [28] & USA & Caucasians & NA & $10 \%$ & Nucleus & & & $40(62.5)$ & $56(60.7)$ & 7 \\
\hline Klump 1997 [15] & Germany & Caucasians & NA & $0 \%$ & Nucleus & & $68(2.9)$ & $27(63)$ & $5(100)$ & 8 \\
\hline Fogt 1998 [27] & USA & Caucasians & NA & $0 \%$ & Nucleus & & & $10(90)$ & $8(87.5)$ & 7 \\
\hline Sato 1999 [26] & Japan & Asians & NA & NA & Nucleus & $35(14.3)$ & $105(41)$ & $55(67.3)$ & $11(90.9)$ & 6 \\
\hline Hirota 2000 [25] & Japan & Asians & NA & Focal or diffuse & Nucleus & & & $40(60)$ & $13(92.3)$ & 6 \\
\hline Ishitsuka 2001 [24] & Japan & Asians & NA & Local or diffuse & Nucleus & & $23(0)$ & $13(61.5)$ & $4(75)$ & 6 \\
\hline Brüwer 2002 [23] & Germany & Caucasians & NA & $0 \%$ & Nucleus & $10(0)$ & $15(6.7)$ & $16(37.5)$ & $14(57.1)$ & 9 \\
\hline Li 2004 [17] & China & Asians & 44 & $10 \%$ & Nucleus & $25(0)$ & $5(0)$ & $14(21.4)$ & $2(50)$ & 7 \\
\hline Yoshida 2004 [22] & Japan & Asians & NA & Scattered & Nucleus & $7(28.6)$ & $19(26.3)$ & $46(63)$ & $7(57.1)$ & 7 \\
\hline Wang 2005 [30] & China & Asians & 44 & $1 \%$ & Nucleus & & $25(4)$ & $7(42.9)$ & $8(50)$ & 8 \\
\hline Wang 2008 [31] & China & Asians & 32 & $5 \%$ & Nucleus & $10(10)$ & $20(15)$ & & & 6 \\
\hline Alkim 2009 [37] & Turkey & Caucasians & 46 & $0 \%$ & Nucleus & $10(40)$ & $26(88.5)$ & & & 7 \\
\hline Kawamata 2011 [14] & Japan & Asians & $28-60$ & NA & Nucleus & $12(0)$ & $8(12.5)$ & $8(62.5)$ & $8(75)$ & 8 \\
\hline Tanaka 2011 [36] & Japan & Asians & 49.5 & Focal & Nucleus & & $28(0)$ & $81(59.3)$ & $10(90)$ & 6 \\
\hline Gushima 2011 [35] & Japan & Asians & 49 & $10 \%$ & Nucleus & & & $11(72.7)$ & $14(21.4)$ & 8 \\
\hline Scarpa 2013 [34] & Italy & Caucasians & 51 & NA & Nucleus & $11(9.1)$ & $19(5.3)$ & $10(20)$ & $7(57.1)$ & 8 \\
\hline Shigaki 2013 [32] & Japan & Asians & $26-80$ & $5 \%$ & Nucleus & & & $58(46.6)$ & $27(59.3)$ & 7 \\
\hline Wohl 2013 [33] & Czech Republic & Caucasians & NA & $33 \%$ & Nucleus & $10(0)$ & $16(6.3)$ & & & 7 \\
\hline
\end{tabular}




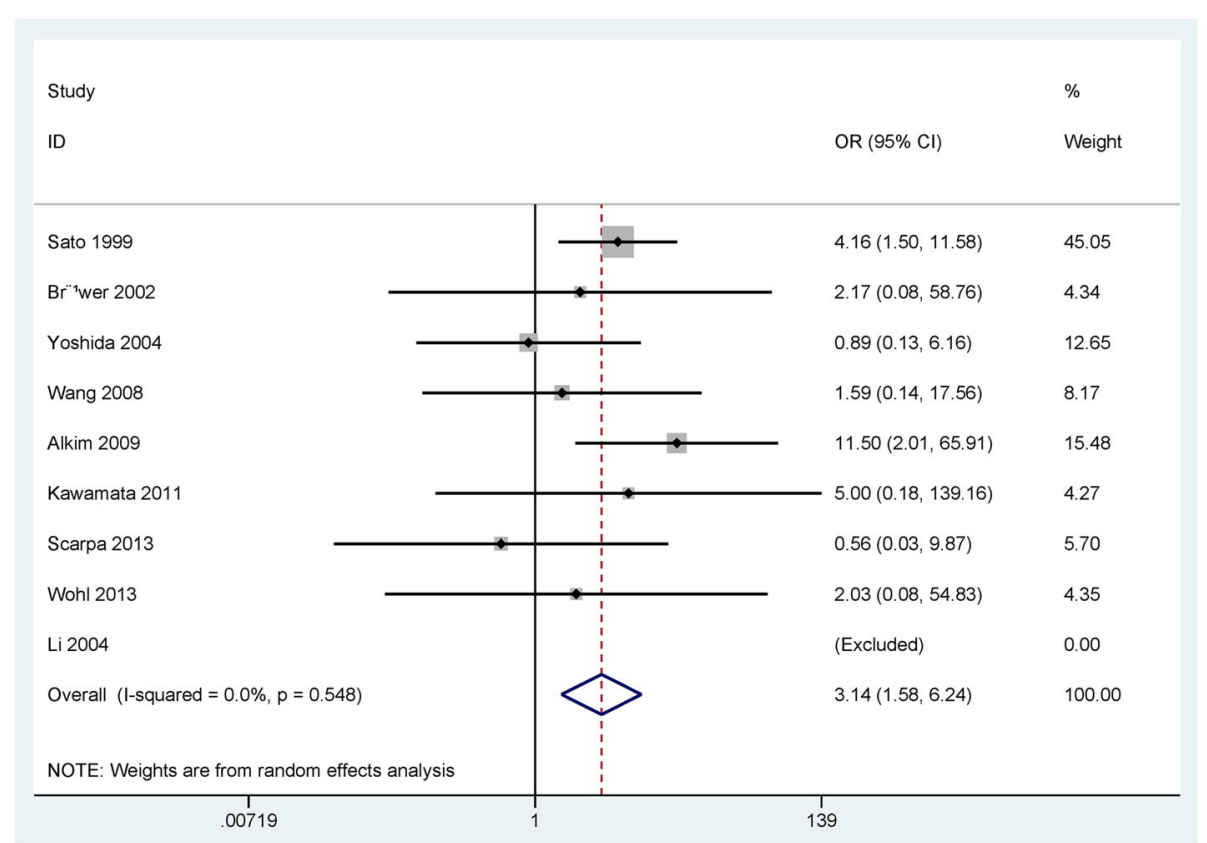

Fig. 2 Forest plot of the pooled OR of p53 expression in UC without dysplasia or carcinoma versus normal tissue samples

Caucasian populations $(\mathrm{OR}=8.28,95 \% \mathrm{CI}=3.08-22.25$, $P<0.001 ; \mathrm{OR}=18.47,95 \% \mathrm{CI}=5.62-60.71, P<0.001)$.

\section{Association of p53 expression in UC with carcinoma versus UC with dysplasia}

The result from the comparison of $215 \mathrm{UC}$ with carcinoma and $456 \mathrm{UC}$ with dysplasia indicated that the frequency of p53 expression in UC with carcinoma was significantly higher than in UC with dysplasia $(\mathrm{OR}=1.69,95 \% \mathrm{CI}=1.04-$ 2.76, $P=0.035$ ) (Fig. 4).

Subgroup analysis based on ethnicity (Asians and Caucasians) showed that p53 expression was not associated with UC-CRC in both Caucasians and Asians $(\mathrm{OR}=1.60,95 \% \mathrm{CI}=0.89-2.86, P=0.116$; OR $=1.65$, $95 \% \mathrm{CI}=0.77-3.56, P=0.198$; respectively) (Table 2 ).

Table 2 Subgroup analysis of ethnicity regarding p53 expression

\begin{tabular}{lcll}
\hline Subgroup (ethnicity) & OR $(95 \% \mathrm{Cl})$ & Heterogeneity: $P$ & $P$ value \\
\hline UC with cancer vs. UC with dysplasia & & \\
Caucasian & $1.60(0.89-2.86)$ & 0.459 & 0.116 \\
Asians & $1.65(0.77-3.56)$ & 0.104 & 0.198 \\
UC with dysplasia vs. UC & & \\
Caucasian & $18.47(5.62-60.71)$ & 0.325 & $<0.001$ \\
Asians & $8.28(3.08-22.25)$ & 0.071 & $<0.001$ \\
UC vs. normal tissues & & & 0.083 \\
Caucasian & $3.49(0.85-14.34)$ & 0.317 & 0.012 \\
Asians & $2.85(1.25-6.47)$ & 0.521 & \\
\hline
\end{tabular}

UC ulcerative colitis, OR odds ratio, $95 \%$ Cl 95\% confidence interval
Sensitivity analysis in UC with dysplasia versus UC without dysplasia/carcinoma

A slight heterogeneity was found in $\mathrm{UC}$ with dysplasia versus $\mathrm{UC}$ without dysplasia/carcinoma $(P=0.027)$. When one study (Klump 1997 et al. [15]) was removed, and the overall $\mathrm{OR}$ value was re-calculated $(\mathrm{OR}=7.28,95 \%$ $\mathrm{CI}=3.48-15.21), P<0.001)$, with no evidence of heterogeneity $(P=0.181)$.

\section{Publication bias}

Egger's test showed that no publication bias was observed in the comparison of UC without dysplasia/carcinoma and normal tissue samples and the comparison of UC with carcinoma and UC with dysplasia $(P>0.1)$ (Fig. 5). A slight publication bias was found in UC with dysplasia versus UC without dysplasia and carcinoma $(P=0.023<0.05)$ (Fig. 5).

\section{Discussion}

TSG p53 expression has been frequently reported in human malignancies [38, 39]. Some studies suggest that positive expression of the p53 gene is linked to the development and progression of tumors [40-42]. Immunohistochemical analysis of p53 protein expression is also found in patients with UC $[32,34]$. However, the results regarding p53 expression in different pathological types of UC are still inconsistent and conflicting. The present study was carried out to analyze whether p53 expression was associated with the increased risk of UC with dysplasia and carcinoma.

p53 gene showed different expression levels in UCassociated different pathological types, ranging from $0 \%$ 


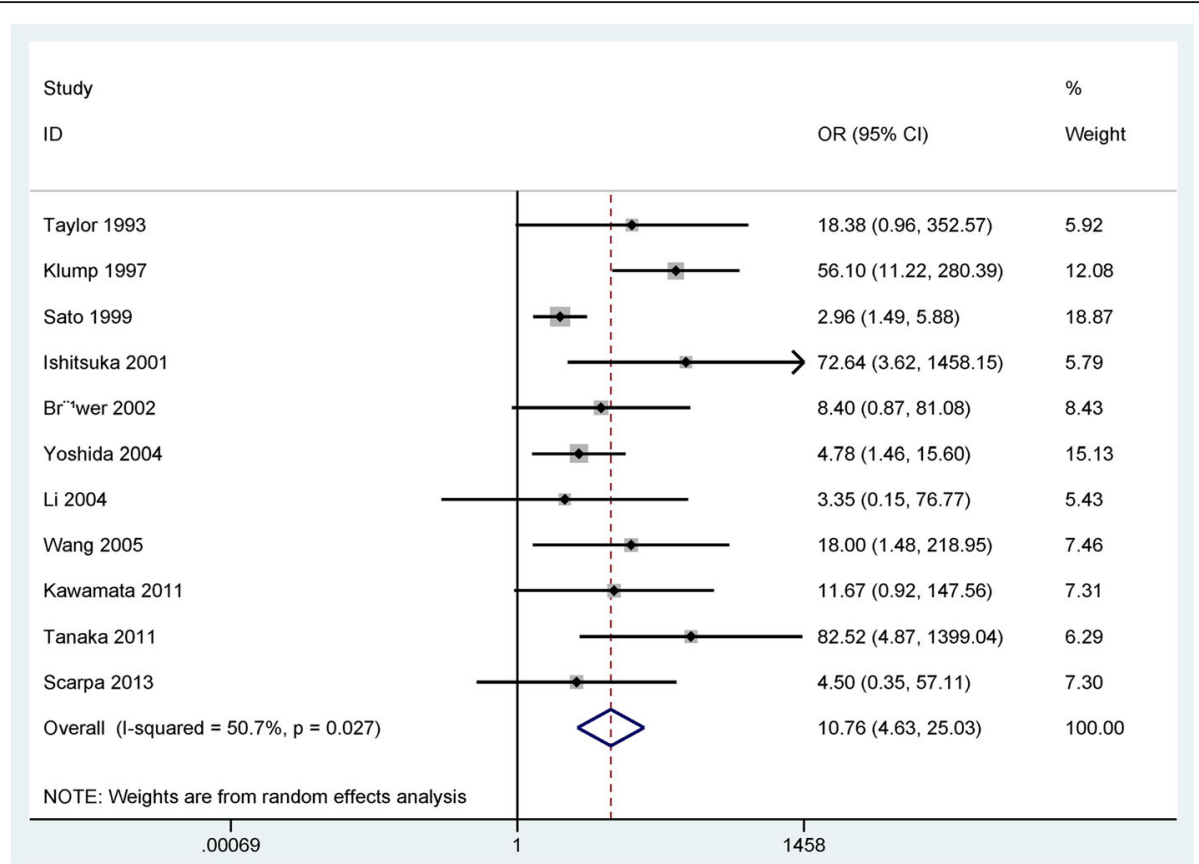

Fig. 3 Forest plot of the pooled OR of p53 expression in UC with dysplasia versus without dysplasia or carcinoma

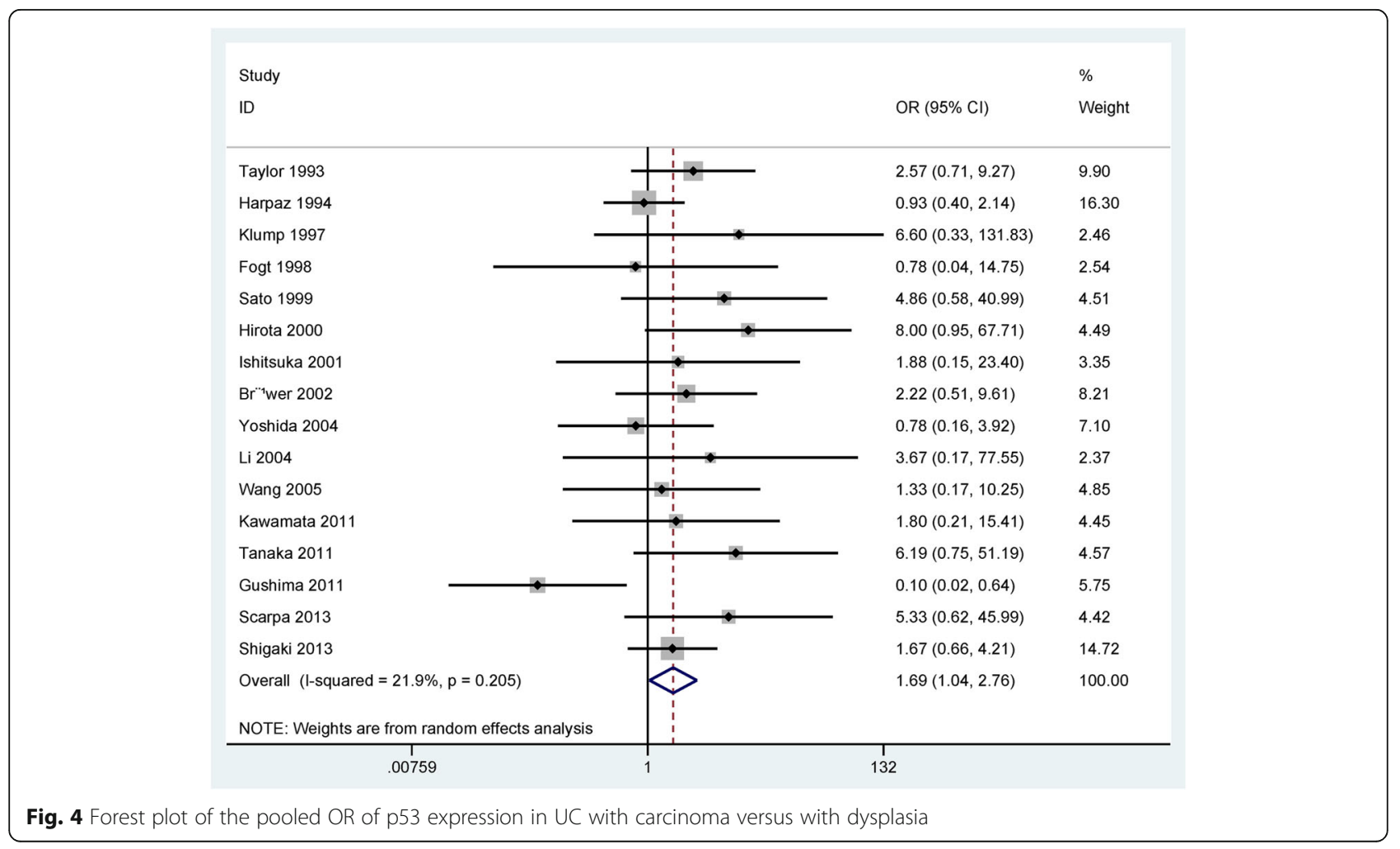




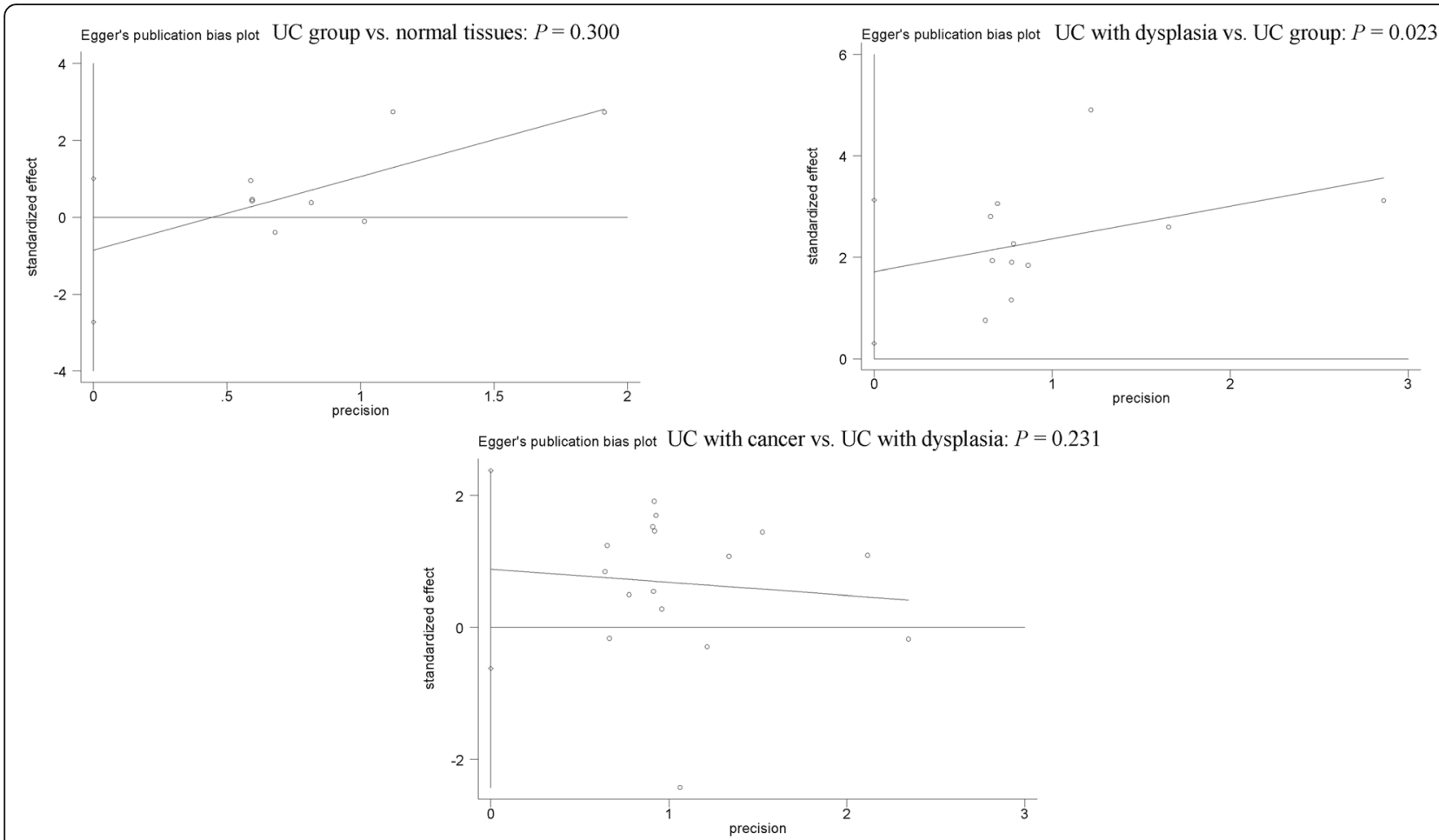

Fig. 5 Forest plot of publication bias using Egger's test

$[14,17,23,33]$ to $40 \%$ [37] in normal tissue samples, and ranging from $0 \%[17,24,29,36]$ to $88.5 \%$ [37] in UC without dysplasia and carcinoma. The expression of the p53 gene had different frequencies in UC with dysplasia or carcinoma, with a range from $20 \%$ [34] to $90 \%$ [27] in UC with dysplasia, and with a range from $21.4 \%$ [35] to $100 \%$ [15] in UC with CRC. This study integrated all available studies involving a large population showed that immunohistochemical detection of p53 protein expression was significantly higher in UC with CRC than in UC with dysplasia, higher in UC with dysplasia than in UC without dysplasia and carcinoma, and higher in UC without dysplasia and carcinoma than in normal tissue samples, which suggested that p53 expression was closely linked to UC-CRC carcinogenesis and the progression of UC with dysplasia. In addition, a slight heterogeneity was detected in UC with dysplasia versus UC without dysplasia and carcinoma $(P=0.027<0.1)$. Thus, we conducted a sensitivity analysis to assess the change of the pooled OR and heterogeneity based on the omission of one study. We removed one study [15], and a re-calculated OR was not significantly changed, with no evidence of heterogeneity $(P=0.181)$, suggesting the stability of the current result. The reasons of heterogeneity from this study and other studies were not clear, perhaps due to the use of inappropriate or different conditions in IHC method, which may cause an observed bias.
Subgroup analysis of ethnicity (the Asian and Caucasian populations) was performed to find different correlation among different subgroups. When UC without dysplasia and carcinoma was compared to normal tissue samples, the result of subgroup analysis revealed that only Asians were susceptible to p53 expression. When UC with dysplasia was compared to UC without dysplasia and carcinoma, the result showed that the Asian and Caucasian populations were susceptible to p53 expression. When UC with carcinoma was compared to UC with dysplasia, the result demonstrated that Asians and Caucasians were not susceptible to p53 expression.

Some limitations should be noted in the present metaanalysis. First, although a range of online electronic databases was systematically searched to identify available publications. Egger's test demonstrated a slight publication bias in UC with dysplasia vs. UC without dysplasia and carcinoma. Only papers published in English or Chinese were included in this meta-analysis. The unpublished articles or conference abstracts were excluded because of insufficient information. Articles with positive conclusions were usually published than these articles with negative conclusions. Second, the main ethnic groups consisted of Asians and Caucasians in this study, but other study populations, such as African population, were lacking. Finally, three eligible studies reported the data between p53 expression and dysplasia and cancer in patients with Crohn's disease (CD) $[37,43,44]$, more studies with large sample 
sizes are essential to further perform a meta-analysis to assess the correlation of p53 expression in CD in the future.

\section{Conclusions}

This study suggests that p53 gene has a notably higher expression frequency in UC-CRC than in UC with dysplasia, higher expression level in UC with dysplasia than in UC without dysplasia and carcinoma, and higher expression rate in UC without dysplasia and carcinoma than in normal tissue samples. Further large-scale clinical trials with large sample sizes are needed to validate our conclusions in the future.

\section{Additional file}

Additional file 1: Table S1. Study quality using Newcastle-Ottawa-Scale (NOS). (DOCX $17 \mathrm{~kb}$ )

\section{Abbreviations}

Cis: Confidence intervals; CRC: Colorectal cancer; IBD: Inflammatory bowel diseases; IHC: Immunohistochemistry; NOS: Newcastle-Ottawa Scale; ORs: Odds ratios; TSG: Tumor-suppressor gene; UC: Ulcerative colitis

\section{Acknowledgements}

Not applicable.

\section{Funding}

None.

\section{Availability of data and materials}

All data and materials were presented within the manuscript and additional supporting files.

\section{Authors' contributions \\ LXH contributed to the conception and design of the current study, wrote the article and revised it for important intellectual content. YYJ and TSY contributed to the retrieval of articles, the extraction of data, the calculation of data and the design of the figures and tables. All the authors approved the final paper.}

\section{Ethics approval and consent to participate}

Not applicable.

\section{Consent for publication}

Not applicable.

\section{Competing interests}

The authors declare that they have no competing interests.

\section{Publisher's Note}

Springer Nature remains neutral with regard to jurisdictional claims in published maps and institutional affiliations.

Received: 11 April 2017 Accepted: 3 October 2017

Published online: 25 October 2017

\section{References}

1. Feuerstein JD, Cheifetz AS. Ulcerative colitis: epidemiology, diagnosis, and management. Mayo Clin Proc. 2014;89(11):1553-63.

2. Marchioni Beery R, Kane S. Current approaches to the management of new-onset ulcerative colitis. Clin Exp Gastroenterol. 2014;7:111-32.

3. Choi JK, Kim DW, Shin SY, Park EC, Kang JG. Effect of ulcerative colitis on incidence of colorectal cancer: results from the Nationwide populationbased cohort study (2003-2013). J Cancer. 2016;7(6):681-6.
4. Burisch J, Munkholm P. The epidemiology of inflammatory bowel disease. Scand J Gastroenterol. 2015:50(8):942-51.

5. Ventham NT, Kennedy NA, Adams AT, Kalla R, Heath S, O'Leary KR, Drummond H, Consortium IB, Consortium IC, Wilson DC, Gut IG, Nimmo ER, Satsangi J. Integrative epigenome-wide analysis demonstrates that DNA methylation may mediate genetic risk in inflammatory bowel disease. Nat Commun. 2016;7:13507.

6. Sun M, Zhang L, Shi S. Associations between NRAMP1 polymorphisms and susceptibility to ulcerative colitis/Crohn's disease: a meta-analysis. Immunol Investig. 2016;45(3):255-70.

7. Anderson CA, Boucher G, Lees CW, Franke A, D'Amato M, Taylor KD, Lee JC, Goyette P, Imielinski M, Latiano A, Lagace C, Scott R, Amininejad L, Bumpstead S, Baidoo L, Baldassano RN, et al. Meta-analysis identifies 29 additional ulcerative colitis risk loci, increasing the number of confirmed associations to 47. Nat Genet. 2011:43(3):246-52.

8. Van Assche G, Dignass A, Bokemeyer B, Danese S, Gionchetti P, Moser G, Beaugerie L, Gomollon F, Hauser W, Herllinger K, Oldenburg B, Panes J, Portela F, Rogler G, Stein J, Tilg H, et al. Second European evidence-based consensus on the diagnosis and management of ulcerative colitis part 3: special situations. J Crohns Colitis. 2013;7(1):1-33.

9. McBride OW, Merry D, Givol D. The gene for human p53 cellular tumor antigen is located on chromosome 17 short arm (17p13). Proc Natl Acad Sci U S A. 1986;83(1):130-4.

10. Soussi T. The p53 pathway and human cancer. Br J Surg. 2005;92(11):1331-2.

11. Steele RJ, Thompson AM, Hall PA, Lane DP. The p53 tumour suppressor gene. Br J Surg. 1998;85(11):1460-7.

12. Davelaar AL, Calpe S, Lau L, Timmer MR, Visser M, Ten Kate FJ, Parikh KB, Meijer SL, Bergman JJ, Fockens P and Krishnadath KK. Aberrant TP53 detected by combining immunohistochemistry and DNA-FISH improves Barrett's esophagus progression prediction: a prospective follow-up study. Genes Chromosomes Cancer 2015; 54(2):82-90.

13. Hollstein M, Sidransky D, Vogelstein B, Harris CC. p53 mutations in human cancers. Science. 1991;253(5015):49-53.

14. Kawamata S, Matsuzaki K, Murata M, Seki T, Matsuoka K, Iwao Y, Hibi T, Okazaki K. Oncogenic Smad3 signaling induced by chronic inflammation is an early event in ulcerative colitis-associated carcinogenesis. Inflamm Bowel Dis. 2011;17(3):683-95.

15. Klump B, Holzmann K, Kuhn A, Borchard F, Sarbia M, Gregor M, Porschen R. Distribution of cell populations with DNA aneuploidy and p53 protein expression in ulcerative colitis. Eur J Gastroenterol Hepatol. 1997;9(8):789-94.

16. Du L, Kim JJ, Shen J, Chen B, Dai NKRAS. TP53 mutations in inflammatory bowel disease-associated colorectal cancer: a meta-analysis. Oncotarget. 2017:8(13):22175-86

17. Li J, Lai MD, Huang Q. Alterations of p53 gene and microsatellite instability in ulcerative colitis and ulcerative colitis-associated colorectal cancer. Zhejiang Da Xue Xue Bao Yi Xue Ban. 2004;33(2):108-14.

18. Ding $Y$, Yang $Q$, Wang $B$, Ye G, Tong $X$. The correlation of MGMT promoter methylation and Clinicopathological features in gastric cancer: a systematic review and meta-analysis. PLoS One. 2016:11(11):0165509.

19. Zintzaras E, loannidis JPHEGESMA. Genome search meta-analysis and heterogeneity testing. Bioinformatics. 2005:21(18):3672-3.

20. Lau J, loannidis JP, Schmid CH. Quantitative synthesis in systematic reviews. Ann Intern Med. 1997:127(9):820-6.

21. Egger M, Davey Smith G, Schneider M, Minder C. Bias in meta-analysis detected by a simple, graphical test. BMJ. 1997:315(7109):629-34.

22. Yoshida T, Matsumoto N, Mikami T, Okayasu I. Upregulation of p16(INK4A) and Bax in p53 wild/p53-overexpressing crypts in ulcerative colitisassociated tumours. Br J Cancer. 2004;91(6):1081-8.

23. Bruwer M, Schmid KW, Senninger N, Schurmann G. Immunohistochemical expression of P53 and oncogenes in ulcerative colitis-associated colorectal carcinoma. World J Surg. 2002;26(3):390-6

24. Ishitsuka T, Kashiwagi $\mathrm{H}$, Konishi F. Microsatellite instability in inflamed and neoplastic epithelium in ulcerative colitis. J Clin Pathol. 2001;54(7):526-32.

25. Hirota Y, Tanaka S, Haruma K, Yoshihara M, Sumii K, Kajiyama G, Shimamoto F, Kohno N. pS2 expression as a possible diagnostic marker of colorectal carcinoma in ulcerative colitis. Oncol Rep. 2000;7(2):233-9.

26. Sato A and MacHinami R. p53 immunohistochemistry of ulcerative colitisassociated with dysplasia and carcinoma. Pathol Int 1999: 49(10):858-868.

27. Fogt F, Zhuang Z, Poremba C, Dockhorn-Dworniczak B, Vortmeyer A. Comparison of p53 immunoexpression with allelic loss of p53 in ulcerative colitis-associated dysplasia and carcinoma. Oncol Rep. 1998;5(2):477-80. 
28. Harpaz N, Peck AL, Yin J, Fiel I, Hontanosas M, Tong TR, Laurin JN, Abraham JM, Greenwald BD, Meltzer SJ. p53 protein expression in ulcerative colitisassociated colorectal dysplasia and carcinoma. Hum Pathol. 1994;25(10): 1069-74.

29. Taylor HW, Boyle M, Smith SC, Bustin S, Williams NS. Expression of p53 in colorectal cancer and dysplasia complicating ulcerative colitis. Br J Surg. 1993;80(4):442-4.

30. Wang $\mathrm{H}$, Yan LI, Zhang WW. The expression of P53,K-ras and hMSH2 in ulcerative colitis-associated colorectal cancer. Chinese Journal of Digestion. 2005;

31. Wang YY, QiU B, Yu J, Li XR, Tian YL, Zhang PY, Shi CL, Chen XY. The expression of CD15, myeloperoxidase, P53 and Rb in ulcerative colitis, adenoma, and colorectal cancer. Chin J. Dig. 2008;28(3):194-6.

32. Shigaki K, Mitomi H, Fujimori T, Ichikawa K, Tomita S, Imura J, Fujii S, Itabashi M, Kameoka S, Sahara R, Takenoshita S. Immunohistochemical analysis of chromogranin a and p53 expressions in ulcerative colitis-associated neoplasia: neuroendocrine differentiation as an early event in the colitisneoplasia sequence. Hum Pathol. 2013:44(11):2393-9.

33. Wohl P, Hucl T, Drastich P, Kamenar D, Spicak J, Honsova E, Sticova E, Lodererova A, Matous J, Hill M, Wohl P, Kucera M. Epithelial markers of colorectal carcinogenesis in ulcerative colitis and primary sclerosing cholangitis. World J Gastroenterol. 2013;19(14):2234-41.

34. Scarpa M, Cardin R, Bortolami M, Kotsafti A, Scarpa MC, Pozza A, Maran G, Picciocchi M, Ruffolo C, D'Inca R, Sturniolo GC, Castagliuolo I, Castoro C, Angriman I. Mucosal immune environment in colonic carcinogenesis: CD80 expression is associated to oxidative DNA damage and TLR4-NFkappaB signalling. Eur J Cancer. 2013;49(1):254-63.

35. Gushima M, Hirahashi M, Matsumoto T, Fujita K, Ohuchida K, Oda Y, Yao T, lida M, Tsuneyoshi M. Expression of activation-induced cytidine deaminase in ulcerative colitis-associated carcinogenesis. Histopathology. 2011;59(3):460-9.

36. Tanaka H, Fukui H, Fujii S, Sekikawa A, Yamagishi H, Ichikawa K, Tomita S, Imura J, Yasuda Y, Chiba T, Fujimori T. Immunohistochemical analysis of REG lalpha expression in ulcerative colitis-associated neoplastic lesions. Digestion. 2011:83(3):204-9.

37. Alkim C, Savas B, Ensari A, Alkim H, Dagli U, Parlak E, Ulker A, Sahin B. Expression of p53, VEGF, microvessel density, and cyclin-D1 in noncancerous tissue of inflammatory bowel disease. Dig Dis Sci. 2009:54(9):1979-84.

38. Inoue K, Kurabayashi A, Shuin T, Ohtsuki Y, Furihata M. Overexpression of p53 protein in human tumors. Med Mol Morphol. 2012:45(3):115-23.

39. Baas IO, Mulder JW, Offerhaus GJ, Vogelstein B, Hamilton SR. An evaluation of six antibodies for immunohistochemistry of mutant p53 gene product in archival colorectal neoplasms. J Pathol. 1994;172(1):5-12.

40. Alaizari NA, Tarakji B, Al-Maweri SA, Al-Shamiri HM, Darwish S, Baba F. p53 expression in pleomorphic adenoma of salivary glands: A systematic review and meta-analysis. Arch Oral Biol. 2015;60(9):1437-41.

41. Mitchell S, Mayer E, Patel A. Expression of p53 in upper urinary tract urothelial carcinoma. Nat Rev Urol. 2011;8(9):516-22.

42. Junior AT, de Abreu Alves F, Pinto CA, Carvalho AL, Kowalski LP, Lopes MA Clinicopathological and immunohistochemical analysis of twenty-five head and neck osteosarcomas. Oral Oncol. 2003:39(5):521-30.

43. Laurent C, Svrcek M, Flejou JF, Chenard MP, Duclos B, Freund JN, Reimund JM. Immunohistochemical expression of CDX2, beta-catenin, and TP53 in inflammatory bowel disease-associated colorectal cancer. Inflamm Bowel Dis. 2011;17(1):232-40

44. Romero M, Artigiani R, Costa H, Oshima CT, Miszputen S, Franco M. Evaluation of the immunoexpression of COX-1, COX-2 and p53 in Crohn's disease. Arq Gastroenterol. 2008:45(4):295-300.

\section{Submit your next manuscript to BioMed Central and we will help you at every step:}

- We accept pre-submission inquiries

- Our selector tool helps you to find the most relevant journal

- We provide round the clock customer support

- Convenient online submission

- Thorough peer review

- Inclusion in PubMed and all major indexing services

- Maximum visibility for your research

Submit your manuscript at www.biomedcentral.com/submit
Biomed Central 